\begin{tabular}{|c|c|c|c|}
\hline Dokumenttype & NOU 1987:23 & Dokumentdato & $1987-06-30$ \\
\hline Tittel & \multicolumn{3}{|c|}{ Retningslinjer for prioriteringer innen norsk helsetjeneste. } \\
\hline Utvalgsnavn & \multicolumn{3}{|c|}{ Prioriteringsutvalget } \\
\hline Utvalgsleder & \multicolumn{3}{|l|}{ Lønning Inge } \\
\hline Utgiver & \multicolumn{3}{|c|}{ Sosialdepartementet } \\
\hline Oppnevnt & $1985-05-24$ & Sider & 104 \\
\hline Kapittel & \multicolumn{3}{|l|}{2} \\
\hline & \multicolumn{3}{|c|}{$\begin{array}{l}\text { Sammendrag av utredningen } \\
\text { Kap. 1. Innledning }\end{array}$} \\
\hline
\end{tabular}

Utvalget tar utgangspunkt i avsnittet om den medisinske utvikling og behovet for bevisste helsepolitiske prioriteringer i Regjeringens langtidsprogram for perioden 1986 - 1989. Det redegjøres i innledningen for utvalgets sammensetning, mandat og arbeidsform og for forholdet til det utredningsarbeid som samtidig utføres av Helseinstitusjonsutvalget.

I arbeidet med løsningen av sin oppgave har utvalget lagt vekt på at utredningen skal tjene som delgrunnlag for den Nasjonale Helseplan som er tenkt fremlagt for Stortinget i lopet av 1988.

\title{
Kapittel 2
}

Sammendrag av utredningen

Kap. 3. Om utvalgets mandat

Utvalget er bedt om å utarbeide retningslinjer for prioriteringer innenfor helsevesenet. Retningslinjer for prioriteringer forutsetter at det først kan etableres enighet om hva det vil si å prioritere. Utvalget legger derfor betydelig vekt på å klargjøre prioriteringsbegrepet og vise hvorfor det er blitt mer og mer sentralt i moderne helsepolitikk. Et vilkår for meningsfylt bruk av prioriteringsbegrepet er etter utvalgets oppfatning at det ved enhver omfordeling av ressurser gjøres klart både hvilke(t) formål som flyttes frem og hvilke(t) som flyttes tilbake på den samlede liste over tiltak som skal tilgodeses med offentlige bevilgninger til helseformål.

Dersom denne klargjøring mangler, er det erfaringsmessig fare for at det enten ikke lykkes å omsette den aktuelle målsetting i praktisk politikk, eller at omfordelingen av ressurser på tilfeldig måte rammer formål som ikke er tilsiktet ned-prioritert. I begge tilfelle vil resultatet bli avstand mellom politisk målsetting/tilsiktet prioritering og praktisk politikk/faktisk prioritering.

Teoretisk er det mulig å forestille seg et altomfattende prioriteringssystem, der alle helsevesenets oppgaver er plassert i en innbyrdes rangorden. I praksis vil ambisjonsnivået for en helsepolitikk basert på bevisste prioriteringer måtte være vesentlig mer beskjedent: Å tilrettelegge bruken av helsevesenets ressurser slik at den fremmer de overordnede målsettinger for helsepolitikken. Skal det lykkes, må både målsettingene være avklaret og virkningene av de tiltak som står til rådighet være kjent. Metodene for prioriteringsbeslutninger må videre være slik at de fører til et fleksibelt prioriteringssystem, der de ulike tiltak til enhver tid kan flyttes ettersom faglig utvikling, samfunnsmessige behov eller endringer i oppfatning av helsepolitiske mål gjør det ønskelig.

Retningslinjene for prioriteringer innenfor helsevesenet bør etter utvalgets oppfatning utformes slik at de kan anvendes uavhengig av hvorvidt de samlede økonomiske ressurser til helsesektoren øker, avtar eller står stille. Utvalget finner det likevel riktig å gjøre oppmerksom på at mulighetene for å gjennomføre omprioriteringer ikke er upåvirket av 
hvorledes ressurstilgangen til helsevesenet utvikler seg. I noen grad vil prioriteringer innenfor helsevesenet være avhengig av samfunnets prioritering av helsetjenesten i forhold til andre offentlige virksomhetsområder.

Utvalget peker på at debatten om ressurskrise og prioriteringer innenfor helsevesenet ikke er et særnorsk fenomen, men avtegner et felles mønster $\mathrm{i}$ land med et høyt materielt velstandsnivå bygget på vitenskap og teknologi. Fordi veksten i ny kunnskap og mulige nye kostnadskrevende behandlingsformer og tiltak øker stadig raskere og trekker etter seg en tilsvarende rask vekst i forventninger og krav til helsetilbud samtidig som veksten i tilgjengelige offentlige ressurser har stagnert eller er avløst av nedgang, blir behovet for å treffe bevisste valg og dermed foreta reelle prioriteringer, stadig mer påtrengende. Etter utvalgets vurdering er det all grunn til å regne med at avstanden mellom det medisinsk mulige og det økonomisk mulige vil fortsette å øke i årene som kommer. Det gjør det desto mer nødvendig å legge premissene for en meningsfylt debatt om prioriteringer der både fagfolk og brukere av helsetjenesten kan delta.

En forutsetning for de politiske beslutninger om prioriteringer som etter utvalgets oppfatning vil bli nødvendige, vil være at det kan etableres en tilstrekkelig enighet i opinionen omkring de grunnleggende prinsipper, målsettinger og retningslinjer for prioriteringer. Dette kan bare skje gjennom åpen og fordomsfri debatt. Utvalget har sett det som sin viktigste oppgave å formulere problemstillingene for en slik debatt og legge frem sine anbefalinger og vurderinger $\mathrm{i}$ en form som kan invitere til den bredest mulige deltakelse i debatten.

\section{Kapittel 2}

Sammendrag av utredningen

Kap. 4. Status og utviklingslinjer for norsk

helsetjeneste

De utfordringer helsetjenesten står overfor, vil etter utvalgets oppfatning bare kunne møtes gjennom en helsepolitikk som makter å gjennomføre reelle prioriteringsbeslutninger. Et system med økende lokalt og regionalt ansvar for helsetjenesten vil bare kunne virke etter hensikten dersom det samtidig utformes en klart profilert helsepolitikk på nasjonalt nivå. De overordnede helsepolitiske føringer må stimulere de politiske beslutningstakere på alle nivå og det faglige og administrative personale innenfor helsevesenet til å fremme de tiltak og tjenester som det er fattet vedtak om å prioritere frem. Det innebærer at evnen og viljen til å holde igjen på ressursforbruket til andre tiltak og tjenester må styrkes.

Utvalget forutsetter at den nåværende styringsstruktur med statlig, fylkeskommunal og kommunal ansvarsfordeling i hovedsak vil bli opprettholdt i årene fremover. Det er grunn til å regne med at det "blandingssystem" som i vårt land er utviklet mellom nasjonal kontroll og målstyring, lokalt selvstyre og privat initiativ, vil bli videreført i nye former. Den offentlige styring bør også i fortsettelsen ha som overordnet mål å sørge for en mest mulig rettferdig fordeling av helsetjenester geografisk og sosialt. I de nærmeste årene fremover vil den største utfordring i norsk helsepolitikk etter utvalgets oppfatning bli å få bygget ut tjenester og tiltak som møter de aller mest svakstilte pasientgruppers behov. Det vil først og fremst si:

- (Enslige) eldre og funksjonshemmede, både i og utenfor institusjon.

- Psykiatriske pasienter, både i og utenfor institusjon.

- Psykisk utviklingshemmede, både i og utenfor institusjon.

Disse utfordringene har et omfang og en vanskelighetsgrad som vil stille store krav til samfunnets evne til å prioritere. Det er derfor viktig at det lykkes å utvikle styringsredskaper som kan holde de sterkere deler av 
helsetjenesten innenfor rimelige rammer.

\section{Kapittel 2 \\ Sammendrag av utredningen \\ Kap. 5. Prioriteringsprosessene innenfor \\ norsk helsevesen}

Utvalget har forsøkt å analysere "den historiske utvikling som har ført frem til den nåværende fremgangsmåte i prioriteringsspørsmål" (mandatet) og har påvist at mangfoldet og mangelen på oversikt i de helsepolitiske beslutningsprosessene utgjør et hovedproblem når det gjelder å skape samsvar mellom samfunnets målsettinger og den faktiske utvikling innenfor helsevesenet.

For å gi et tilnærmet realistisk bilde av mangfoldet og uoversiktligheten i dagens prioriteringsprosess gjennomgår utvalget en rekke sentrale eksempler fra dagens norske helsetjenestevirkelighet. Når det er nødvendig å gå såvidt konkret og detljert til verks, henger det sammen med at ansvar og beslutningsmyndighet er sterkt desentralisert, utøves på mange nivå og av mange ulike aktører på hvert enkelt beslutningsnivå. Ikke bare ansvaret for å prioritere mellom pasienter og pasientgrupper, men også store deler av ansvaret for prioritering av bruken av store helsetjenesteressurser er i virkeligheten desentralisert til den enkelte helsearbeider og spesielt til den enkelte lege. Summen av de prioriteringer som blir gjort på grunnplanet låser i stor grad ressursbruken i helsetjenesten. Først i etterhånd synes det mulig å få et tilnærmet dekkende bilde av den faktiske ressursbruk. Dette fører lett til at betydelige penge- og personellressurser settes inn på helt andre måter enn dem de politiske beslutningstakere sier at de har prioritert høyest.

Gjennom den eksempelsamling utvalget har gjennomgått, søker det å gi et inntrykk av mangfoldet og uoversiktligheten i de prosesser som fører til at tiltak innenfor helsetjenesten får, beholder, eller mister prioritet

innenfor systemet. Ut fra sin vurdering av de eksempler som er gjennomgått, trekker utvalget følgende konklusjoner:

- Den organisasjonsmodell for helsetjenesten vi har valgt i Norge med stor grad av desentralisering og svak sentral normsetting og oppfølging, samt det finansieringssystem vi har valgt med en blanding av rammefinansiering, "pakkefinansiering" og stykkprisrefusjon basert på et innviklet takstsystem, har ført til at det er meget vanskelig for noen å ha oversikt over hvordan helsetjenestens ressurser blir prioritert brukt. Dessuten medfører dette tilfeldige ulikheter i tilbudet mellom pasientgrupper og mellom landsdeler.

- Faktiske prioriteringer etableres for ofte uten at det foreligger noen form for kritisk faglig/økonomisk vurdering/forskning, konsensus eller administrative vedtak, og uten forutgående drøfting og vurdering på helsepolitisk ansvarlig nivå.

- Prioriteringsbeslutninger på ansvarlig nivå skjer ofte ad hoc og diktert av foreliggende omstendigheter - ofte etter sterk påvirkning av pressgrupper/koalisjoner av pressgrupper med eller uten medias hjelp uten at de settes inn i noen overordnet plan eller system av prioriteringer.

- Prioriteringsvedtak som det er bred tverrpolitisk enighet om, blir likevel ikke alltid fulgt opp med tilførsel av nødvendige ressurser og/eller nødvendige organisasjonsendringer.

- Omprioriteringer innen et system med ressursknapphet, voksende etterspørsel, velorganiserte interessegrupper og ønske om politisk popularitet, er et virkemiddel med sterkt begrensede muligheter.

- En nødvendig forutsetning for utvikling i retning av mer realistisk og effektiv prioritering er et mer gjennomtenkt og bedre begrunnet sett av 
prinsipper og retningslinjer for prioritering på alle forvaltningsnivåer og alle nivåer innen helsetjenesten.

- Også i fremtiden er det realistisk å regne med sprik mellom idealer og realiteter på prioriteringsfronten. Følgelig er det viktig å søke politisk konsensus og avklaring med hensyn til de viktigste idealer for fremtidens prioriteringsbestrebelser. Åtydeliggjøre slike idealer, prinsipper og retningslinjer er et politisk ansvar, på alle plan i helsesektoren.

\title{
Kapittel 2
}

\author{
Sammendrag av utredningen \\ Kap. 6. Forslag til mål, prinsipper og \\ retningslinjer for prioriteringer i norsk \\ helsetjeneste
}

I sin drøfting av mål, prinsipper og retningslinjer for den fremtidige prioriteringsprosess innenfor norsk helsevesen har utvalget tatt utgangspunkt $\mathrm{i}$ allmenne verdioppfatninger som det er bred enighet om i det norske samfunn. Det synes selvinnlysende at de generelle idealer samfunnet bekjenner seg til - idealer som rettferdighet, likhet og frihet - også skal komme til uttrykk i helsetjenesten. Det må også tas for gitt at den allment aksepterte samfunnsforpliktelse over ressurssvake og underpriviligerte medmennesker i helsetjenesten skal ytre seg som en prioritert forpliktelse overfor de svakest stilte.

Selv om de fleste av de grunnleggende mål og prinsipper for helsetjenesten hver for seg vil være innlysende eller allment aksepterte, legger utvalget vekt på behovet for en gjennomtenkt og helhetlig avveiet forståelse av dem. Det er i en bevisstgjøring av målsettinger og prinsipper også nødvendig å gjennomtenke de problemer som knytter seg til begrepene helse og sykdom og dermed til forståelsen av forholdet mellom helsetjenestens to grunnleggende mål: Å bekjempe sykdom og å fremme helse.

Utvalget legger i denne sammenheng vekt på at en omfattende definisjon av helsebegrepet som et kvalitetsmål på samfunnet og det enkelte individs tilværelse kan gi en nyttig påminnelse om overordnede mål for alle samfunnets politiske bestrebelser. For helsevesenet som profesjonelt tjenesteytende sektor er det imidlertid nødvendig å legge mer nøkterne, presise og avgrensede målsettinger til grunn. Utvalget fester i denne sammenheng oppmerksomheten ved at det er vesentlig enklere å beskrive de delmål som knytter seg til det å bekjempe sykdom mer enn de delmål som knytter seg til det å fremme helse. For forståelsen av den siste hovedmålsetting vil det i årene fremover være særlig viktig å vektlegge sammenhengen mellom innsatsen innenfor helsesektoren og de beslutninger som fattes innenfor andre samfunnssektorer.

Utvalget har i sitt arbeid med utformingen av retningslinjer for prioriteringer lagt stor vekt på å innholdsbestemme begrepet nødvendig helsetjeneste. Utvalget har ikke sett det som sin oppgave å drøfte de juridiske problemer som knytter seg til bruken av nødvendighetsbegrepet i helselovgivningen. Det finner det imidlertid for sin del nyttig å knytte begrepet nødvendig helsetjeneste til en bestemmelse av det minstemål av helsetjeneste hele befolkningen bør sikres tilgang til. En slik definisjon av en minimumsmålsetting vil etter utvalgets oppfatning være et uunnværlig hjelpemiddel i prioriteringsprosessen innenfor helsevesenet. Utvalget er blitt stående ved følgende forslag til formulering av en slik målsetting:

\section{Diagnostikk}

Enhver bør kunne bli raskt og adekvat undersøkt for symptomer/tegn som gir berettiget mistanke om at det foreligger en alvorlig (livstruende, invalidiserende, plagsom) sykdom. 


\section{Behandling}

Enhver bør raskt og adekvat få utført behandling for påvist alvorlig sykdom når det er kjent at behandling i vesentlig grad kan bedre sykdommens prognose (med hensyn til livskvalitet eller -kvantitet). Behandlingsformer regnes som dokumentert effektive når dette har skjedd gjennom kontrollerte kliniske forsøk eller der det foreligger bred konsensus.

\section{Habilitering}

Enhver som har alvorlige kroniske sykdommer og/eller funksjonshemninger bør få hjelp til å oppnå tilnærmet deltagelse og likestilling i samfunnet, og denne hjelp bør såvidt mulig gis på premissene til personen som skal habiliteres.

\section{Pleie}

Enhver som ikke makter å sørge for et tilstrekkelig næringsinntak, som ikke makter å ivareta naturlige funksjoner, hygiene eller påkledning og som har sterkt redusert bevegelighet, mulighet for ytre stimulering eller sosiale kontakter, bør få hjelp som kan sikre disse livsfunksjoner.

\section{Forebyggende medisin}

Enhver bør få informasjon om positive og negative miljøfaktorer og levevaner som i vesentlig grad påvirker livskvalitet og -kvantitet.

\section{Kapittel 2}

Sammendrag av utredningen

Kap. 7. Mandatets fem dimensjoner

De fem prinsipper eller dimensjoner for prioritering som blir spesielt fremhevet i mandatet, er alle viktige, samtidig som de alle trenger en nærmere analyse og avklaring for å kunne anvendes på forsvarlig måte. Den inngående drøfting utvalget har gjennomført i denne sammenheng, gir til resultat at:

- En av de fem dimensjonene skiller seg ut som særlig utslagsgivende i prioriteringssammenheng: Sykdommens alvorlighetsgrad.

- Ingen av de fem dimensjonene kan strykes fra listen over relevante prioriteringskriterier. Alle representerer hensyn som et godt prioriteringssystem må ta med i betraktningen.

- Ingen av de fem dimensjonene kan - med unntak for sykdommens alvorlighetsgrad i enkelte situasjoner - enkeltvis og alene fungere som prioriteringskriterium uten støtte fra et eller flere andre kriterier.

Sammen med effektiviseringskriteriet vil alvorlighetskriteriet måtte tjene som det viktigste kriterium for prioriteringsbeslutninger innenfor norsk helsetjeneste i fremtiden. Det er imidlertid nødvendig å være oppmerksom på at heller ikke disse kriterier uten videre er entydige eller lar seg anvende uten skjønnsmessige avveininger av ulike hensyn i den enkelte beslutningssituasjon.

Likhetskriteriet byr på større tolknings- og avgrensningsproblemer. Det likhetsprinsipp utvalget etter inngående drøftinger er blitt stående ved, er at helsetjenestene bør utformes og organiseres slik at alle får den samme adgang til å bli så friske som de etter sine forutsetninger har mulighet for. Dette prinsipp bør søkes realisert uavhengig av sosiale, geografiske og aldersbetingede ulikheter.

Ventelister har åpenbare funksjoner i prioriteringssammenheng. Noen av disse funksjonene er nødvendige og uunnværlige. Det er de unødvendige ventelister og køer som bør forsvinne. Å utarbeide mer entydige kriterier for ventelisteføring er derfor en sentral oppgave i prioriteringssammenheng. 
Det kriterium som utvalgets mandat kaller helseøkonomiske aspekter, rommer vanskelige problemer. Det er omstridt hva helseøkonomi er og bør være, f.eks. når det gjelder sammenhengen mellom effektiv utnyttelse av helsetjenestens mange ulike ressurser og en kvalitetsmessig høyverdig helsetjeneste. Helseøkonomi som vitenskap er et nytt fagområde som ennå ikke har funnet sin plass og form. I dagens situasjon, hvor presset på helsetjenestens ressurser er økende, er behovet for en dypere forståelse av helseøkonomiske problemstillinger påtrengende. Utvalget understreker i denne sammenheng at det er viktig å skille mellom helseøkonomiske og produktivitetsfremmende beslutninger på populasjonsnivå - det er på dette nivå slike beslutninger hører hjemme - og det å ta økonomiske hensyn i pasientbehandlingen på primærnivå. På begge nivåer er det rimelig, nødvendig og moralsk forsvarlig å ta økonomiske hensyn, men de to beslutningsnivåer er meget ulike sett fra et medisinsk-etisk synspunkt. I likhet med sykdommens alvorlighetsgrad må også økonomidimensjonen i helsetjenesten innpasses i en større helhet av kriterier og hensyn.

Den femte dimensjon i mandatet reiser spørsmålet om selvpåførte helseskader bør få prioritetsmessige konsekvenser for den enkelte pasient. Spørsmålet besvares av utvalget i hovedsak med nei. Utviklingen av de såkalte "livsstilssykdommer" må først og fremst møtes gjennom aktiv informasjon og forebyggende tiltak rettet mot hele befolkningen, ikke ved moraliserende reaksjoner overfor den enkelte pasient som har behov for hjelp og omsorg. Utvalget peker likevel på at det kan være behov for klare holdninger i kommunikasjonen med den enkelte pasient; det er ikke forsvarlig å foreta omfattende og risikopregede inngrep uten at pasienten er innstilt på å gjøre de forandringer i sine levevaner som under enhver omstendighet vil være et vilkår for et tilfredsstillende resultat av behandlingen. Det er heller ikke forsvarlig å gjenta slik behandling for notorisk selvpåført sykdom og skade i tilfeller hvor det er klart at pasienten overser den informasjon og veiledning eller direkte motsetter seg de råd som er gitt som forutsetning for behandlingen.

\title{
Kapittel 2
}

\author{
Sammendrag av utredningen \\ Kap. 8. Hovedtyper av virkemidler i \\ prioriteringsprosessen
}

Et hovedproblem i dagens norske helsepolitikk er etter utvalgets

vurdering at det ikke har vært godt nok samsvar mellom de mål de overordnede myndigheter har satt for helsepolitikken, og hvordan virkemidlene er utformet. Etter utvalgets oppfatning har imidlertid myndighetene store og hittil dårlig utnyttede muligheter til å velge virkemidler som er egnet til å fremme de mål og retningslinjer som er formulert i utredningens kap.6. Utvalget peker spesielt på betydningen av at:

- De politiske beslutningstagere og beslutningsorganer blir seg sitt prioriteringsansvar mer bevisst.

- Staten klarlegger sitt ansvar og sin rolle i helsepolitikken.

- Det lages en Nasjonal Helseplan som legges frem for Stortinget.

- Kommuner og fylkeskommuner utvikler bedre planredskaper.

- Det etableres rådgivende grupper innen større medisinske fagområder, forskning og utdanning, og det blir fortgang $i$ arbeidet med målbevisst bruk av konsensuskonferanser.

- Det utvikles bedre målemetoder for hva som faktisk skjer i helsetjenesten.

- Helsetjenesteforskningen styrkes.

Det viktigste virkemiddel for en mer realistisk og effektiv prioriteringsprosess er etter utvalgets oppfatning et mer gjennomtenkt og begrunnet system av prinsipper og retningslinjer for prioriteringer på alle 
nivåer i helsetjenesten. I kap.9 har utvalget forsøkt å vise hvorledes de grunnleggende prinsipper og retningslinjer kan konkretiseres og utformes til et system med ulike prioriteringsnivåer for de aktuelle tiltak innenfor helsetjenesten. Den store utfordring i norsk helsepolitikk vil etter utvalgets oppfatning bli å få aksept for at prioriteringer betyr at noe må settes bakerst i køen av i og for seg ønskverdige tiltak og tjenester. Det er på denne bakgrunn sterkt ønskelig at utvalgets forslag kan utløse en bred og engasjert helseprioriteringsdebatt i Storting, fylkesting, kommunestyrer, fagforeninger, politiske og andre organisasjoner og i media.

\section{Kapittel 2}

Sammendrag av utredningen

Kap. 9. Et prioriteringssystem med fem

prioriteringsnivåer

Et prioriteringssystem i helsevesenet må utformes og anvendes med skjønnsomhet og fleksibilitet. Samtidig må det forene fleksibiliteten med en relativt fast og enkel struktur. Det systemet utvalget foreslår i dette kapittel, har fem prioriteringsnivåer eller kategorier. Fire av disse definerer ulike grader av positiv prioritering, jfr. kap. 3.1.4. Det femte prioriteringsnivå rommer tiltak som ikke er prioriterte, dvs. tiltak som etter utvalgets vurdering bør ha null-prioritet. Systemet er knyttet til utbyggingen av tiltak og tjenester og er derfor først og fremst beregnet på å kunne anvendes på beslutningstagere på politisk nivå. Systemet er et normativt system, som tar sikte på å angi hvordan de enkelte typer tiltak bør være utbygd i forhold til hverandre for å inneha sin riktige plass i prioriteringshierarkiet. For å kunne anvende systemet i tilknytning til konkrete prioriteringsbeslutninger trenges det i tillegg også kunnskap om den faktiske prioritering av de(t) aktuelle tiltak. Bare avstanden mellom ideell og faktisk prioritering kan avgjøre hvorvidt et tiltak fortjener å flyttes frem eller ikke.

Utvalget har søkt å definere de fem prioriteringsnivåene så klart som mulig. Ved å anføre eksempler på hvilke tiltakstyper som bør høre hjemme på de enkelte nivåer, har det videre forsøkt å konkretisere bruken av definisjonene så langt som mulig.

Første prioritet skal etter utvalgets anbefaling være reservert for tiltak som er nødvendige i den forstand at det har umiddelbart livstruende konsekvenser for enkeltpersoner, pasientgrupper eller samfunnet som helhet, dersom de ikke iverksettes øyeblikkelig.

Eksempler på tiltak som etter utvalgets oppfatning hører hjemme på dette nivå, er:

- Akutt psykiatri, f.eks. tiltak som ivaretar øyeblikkelig-hjelp-plikten i

psykiatrien.

- Akutt kirurgi, f.eks. akutt abdomen og skader.

- Nyfødtmedisin, f.eks. intensivmedisin og korrigering av alvorlige medfødte lidelser.

- Tiltak for akutt pleietrengende, jfr. også kap.6.6.

- Akutt indremedisin, f.eks. tiltak ved alvorlig sirkulasjons- og

respirasjonssvikt, coma diabeticum, transfusjon av blødere.

- Forebyggelse og beredskap mot alvorlige smittsomme sykdommer, f.eks. mot

AIDS, smittsom hjernehinnebetennelse.

- Katastrofeberedskap.

Annen prioritet skal være for tiltak som er nødvendige i den forstand at svikt får katastrofale eller svært alvorlige konsekvenser på lengre sikt for enkeltpasienter, pasientgrupper eller samfunnet som helhet.

Eksempler på tiltak som etter utvalgets oppfatning hører hjemme på dette nivå, er:

- Tiltak innen kommune- og fylkeshelsetjenestens diagnostiske og 
terapeutiske apparat som er spesielt innrettet på personer med alvorlige og kroniske - psykiske og somatiske - lidelser, f.eks. kreft, hjertesvikt, psykoser, alvorlige nevroser, diabetes, alvorlige rheumatiske og ortopediske lidelser, kroniske nevrologiske lidelser, alvorlige syns- og hørselslidelser.

- Omsorgs- og pleietiltak for pasienter med store, kroniske pleiebehov, f.eks. hele eldreomsorgskjeden, sykehjem, hjemmesykepleien, hjemmefysioterapi, ergoterapi og hjemmehjelp samt terminalpleien.

- Helsetjenester spesielt tilrettelagt for visse grupper alvorlig funksjonshemmede.

- Deler av den forebyggende helsetjenesten, f.eks. svangerskaps- og spedbarnskontroll, helsestasjonsvirksomhet, prevensjonsveiledning, deler av skolehelsetjenesten (syns- og hørselstester), genetisk veiledning og screening av høyrisikogrupper.

Tredje prioritet skal være for tiltak med dokumentert nytteeffekt, hvor konsekvensene av svikt er klart uønskede, men uten å være så alvorlige som under første og annen prioritet.

Eksempler på tiltak som etter utvalgets oppfatning hører hjemme på dette nivå, er:

- Tiltak innen kommune- og fylkeshelsetjenestens diagnostiske og terapeutiske apparat som er innrettet på pasienter med moderate - akutte og kroniske - helseproblemer, f.eks. personer med moderat forhøyet blodtrykk, de vanlige barnesykdommer, ukomplisert brokk, åreknuter, moderate psykiske problemer.

- Deler av den forebyggende helsetjeneste, f.eks. den yrkesmedisinske del av bedriftshelsetjenesten, familierådgivningskontorene, screening av grupper med moderat forhøyet sykdomsrisiko, helseopplysning som grunnlag for egenomsorg.

Fjerde prioritet skal være for etterspurte tiltak med antatt helse- og livskvalitetsfremmende effekt, der skadevirkningene ved svikt er klart mindre tungtveiende enn ved svikt i tiltak av høyere prioritet.

Eksempler på tiltak som etter utvalgets oppfatning hører hjemme på dette nivå, er:

- Høyteknologisk medisin med svak dokumentert nytteeffekt, f.eks. rutinemessig ultralydundersøkelse flere ganger i svangerskapet.

- Fysioterapi som ikke har dokumentert effekt på alvorlige og invalidiserende sykdommer.

- Kunstig inseminasjon og befruktning utenfor kroppen.

- Legetjenester ved ufarlig og selvbegrensende sykdom f.eks. forkjølelse.

- Rekreasjonsopphold uten aktivt rehabiliteringsopplegg.

Null prioritet er nivået for helsetjenester som er etterspurte, men som verken er nødvendige eller har klart dokumentert nytteverdi.

Eksemler på tiltak som etter utvalgets oppfatning hører hjemme på dette nivå, er:

- Høyteknologisk medisin uten kjent nytteeffekt, f.eks. ukritisk bruk av magnettomografisk undersøkelse.

- Ny kostnadskrevende diagnose og behandling uten dokumentert bedre effekt enn allerede eksisterende diagnose- og behandlingsformer.

- Rutinemessig bruk av laboratorie- og billeddannende undersøkelser på svake indikasjoner.

- Deler av skolehelsetjenesten, f.eks. rutinemessig måling og veiing.

- Spesialtilbud for konkurranseidrettsutøvere.

- Personallegedelen av bedriftshelsetjenesten.

- Rutinemessige helsekontroller og screening av friske individer uten forhøyet risiko.

Utvalget har med dette utformet forslag til en innbyrdes rangordning mellom tiltak innenfor norsk helsetjeneste. Forslaget innebærer på vesentlige punkter en helsetjeneste som er forskjellig fra den eksisterende. En hovedretningslinje for de omprioriteringer av ressurser som vil trenges, må etter utvalgets oppfatning være at det ikke skal nyttes offentlige ressurser til tiltak som er på prioriteringsnivå 4 og lavere før tiltak som omfattes av prioriteringsnivåene 1, 2 og 3 er tilfredsstillende utbygget over hele landet.

Ved fordelingen av ressursene mellom prioritetsnivå 1, 2 og 3 antar utvalget at alle kategoriene må sikres et tilfredsstillende utbyggingsnivå, 
og et stykke på vei må dette skje parallelt. Hva som kan regnes som et tilfredsstillende utbyggingsnivå, er imidlertid ulikt for de tre prioriteringskategorier. Det ligger i selve rangordningen at man bør tilstrebe en høyere dekningsgrad for tiltak av første prioritet enn for tiltak av tredje prioritet.

Utvalget understreker at det ut fra det oppstilte normative system ikke uten videre kan trekkes slutninger om hvordan ressurser i dagens situasjon bør kanaliseres. Heller ikke kan man ut fra plasseringen på prioritetsnivå automatisk slutte seg til hvor stor andel av omdisponerbare ressurser de enkelte tiltak bør få. Utslagsgivende vil her avstanden mellom faktisk og ideell prioritering være.

I dagens situasjon antar utvalget på denne bakgrunn at det ikke først og fremst er tiltak av første prioritet som generelt trenger tilførsel av nye ressurser. Disse tiltak synes, i likhet med tiltak av tredje prioritet, langt på vei å være rimelig dekket.

Uoverensstemmelsen mellom ideell og faktisk prioritering har først og fremst rammet tiltak av annen prioritet. I kapittel 5 har vi vist at på tross av uttalte ønsker om opprioritering, har særlig visse omsorgsformer vært utbygd i art og omfang som ligger langt etter eksisterende behov. Vi tenker her særlig på omsorgen for pleie- og omsorgstrengende eldre og omsorgen for psykisk utviklingshemmede. Også ulike tiltak for fysisk sterkt funksjonshemmede er tildels sterkt underprioritert i forhold til behovet.

Utvalget mener for sin del at det i den løpende prioriteringsprosess særlig er tiltak av denne art som har behov for en økt andel av ressursene.

\section{Kapittel 2}

Sammendrag av utredningen

Kap. 10. Økonomiske og administrative

konsekvenser

Utvalget har ikke sett det som sin oppgave å fremme forslag til nye, omfattende tiltak av organisatorisk eller økonomisk karakter, men har forstått mandatet som et pålegg om å fremme forslag til retningslinjer for prioriteringer innenfor den til enhver tid vedtatte økonomiske ramme for helsetjenesten. De anbefalinger som er gitt i utredningen, bør etter utvalgets vurdering kunne gjennomføres innenfor de eksisterende økonomiske rammer.

Når det gjelder forslaget om å utarbeide bedre målemetoder for virksomheten i helsetjenesten, viser utvalget til pågående utredningsarbeid i regi av bl.a. Norske Kommuners Sentralforbund (NKS), Statistisk Sentralbyrå og Sosialdepartementet. Såvidt utvalget kan se, har en tilstrekkelig ressurser på dette området, men det trengs en bedre administrativ samordning av arbeidet. Sosialdepartementet bør påta seg en slik samordning.

Når det gjelder forslaget om å etablere rådgivende grupper innen større medisinske fagområder, forskning og utdanning, forutsetter utvalget at gruppens virksomhet kan innpasses innenfor nåværende økonomiske og personellmessige rammer.

Kostnadene ved å avholde konsensuskonferanser vil være små og bør kunne innpasses innenfor rammen av dagens bevilgninger. 